\title{
Utilization of TV-E in Education Character for Early Childhood
}

\author{
Eldarni \\ Educational Technology \\ Universitas Negeri Padang \\ Padang, Indonesia \\ eldarni16@gmail.com
}

\author{
Zuwirna \\ Educational Technology \\ Universitas Negeri Padang \\ Padang, Indonesia \\ zuwirnawz@gmail.com
}

\author{
Fetri Yeni J \\ Educational Technology \\ Universitas Negeri Padang \\ Padang, Indonesia \\ fetri53829@yahoo.co.id
}

\begin{abstract}
Technological developments are advancing rapidly facilitate us in accessing any kind of information. In various educational units early childhood need so much information, for example information in social, economic, political, science, and education. To get optimal results then all components are designed according to the learning objectives and characteristics of early childhood so that the purpose of character building education for early childhood can be achieved. One of which is the utilization of TV mass media as a way to convey the message of learning based on technology.Awareness to organize the use of TV mass media that benefits life is the best solution. TV programs including educational programs, are usually designed in such a way as to attract children to watch it in order to maximize efforts to change behavior and attitudes. Through TV-E is expected they can take advantage of what they watch especially information that is educational. Through informal educational institutions run by mass media, by instilling the values of character education like the value of honesty responsible, spiritual values and so forth which is inserted through the program being aired.
\end{abstract}

Keywords-TV-E; character education; early childhood

\section{INTRODUCTION}

Character education is a process of transforming the values of life to grow in a person's behavior. As the times progressed, many teenagers did not have good character and in accordance with national education objectives. Therefore, it is very important for parents and educators to begin to instill character education in early childhood. The declining moral character of the nation and the increasingly widespread irregularities that occur in adolescents is indicated by the existence of promiscuity, the rise of violence of children and adolescents, crime against friends, theft of adolescents, cheating, drug abuse, pornography, rape, confiscation, And the destruction of the property of the person undertaken by the students.

Family environment and school environment (Kindergarten/ Early childhood/ Playground) for children, is a place in an effort to build the character of children from an early age. PAUD, in its implementation requires patience for the coach or the educator. In the whole process of education in schools, learning activities are the most important activities and learn about the vast aspects of life. Thorndike defines learning as a process of interaction between stimuli (which may be thoughts, feelings, or movements) and responses (which are also thoughts, feelings or movements[1]. Trianto defines learning as a process changes in behavior remain from unknown to know, from not understanding to understand, from lack of skill to being skilled, and from old habits to new habits, and beneficial to the environment and the individual itself[2]. Learning is a process of changing individual behavior through interaction with the environment[3].

Learning requires effort and persistence. Someone is said to learn when they are ready to get out of the comfort zone and ready to take risks. In order for them to feel drawn out of the comfort zone while at the same time facing these risks, learning is required that challenges them in learning. Learning does not have to be glued to teachers or books as a source of learning, we can also take advantage of existing technology today.

Focus on learning problems, indeed the role of educators and learners become an important subject matter. In learning educators must be able to provide, serve, and guide the participants of educators so that they are able to transform themselves into an achievement of death. However, the growing education in the field of technology we can also take advantage of various media technologies that can serve as a model message in learning.

The rapid development of advanced technology makes it easy to access all sorts of information. In educational units it takes so much information, whether information in the social, economic, political, scientific, educational fields. To obtain optimal results, all components are maximized so that the purpose of character building for early childhood can be achieved, one of which is the utilization of mass media TV as a way to conduct learning messages based on technology. Awareness to organize the use of massive TV media that benefits life is the best solution. The role of the TV mass media in the nation's character building must be based on an Indonesian cultural perspective which lays its foundation within the framework of the Unitary State, with cultural diversity that has noble values, wisdom and local knowledge that is wise and prudent.

Various TV programming programs, including educational programs, are usually designed in such a way as to attract children to watch for the sake of maximizing change in behavior and attitude. Through TV they are expected to benefit from what they watch, especially information that is educational. Through informal educational institutions run by 
the mass media, the values of character education are inserted through the presented impressions. Thus it is expected that the program is able to build characters in children.

\section{LITERATURE REVIEW AND DISCUSS}

The general purpose of television or broadcasting in Indonesia is as follows: 1) to grow and develop the mental of the people of Indonesia who believe and piety to God Almighty. 2) strengthen the unity and unity of the nation and 3) develop a just and prosperous society.

TV functions similar to other mass media functions (newspapers and radio broadcasts), which provide information, educate, entertain and persuade[4]. Basically, television as a tool or electronic mass media used to obtain some information, entertainment, education and so forth. In accordance with the broadcasting law number 24 of 1997 , chapter II article 5 reads "Broadcasting has a function as a medium of information and information, education and entertainment, which strengthens ideology, politics, economy, socio-culture and defense and security."

Many events presented by the television station in between, about the cultural dish of the Indonesian nation, so that it can attract the audience to love the culture of the nation itself, as one of the nation's heritage that needs to be preserved. Television media in general has three functions, namely: 1) Entertainment Function, 2) Information function, 3) Function of education[5].

The use of audio-visual media in the learning process can generate new desires and interests, increase motivation and stimulation of learning activities and even bring psychological influence on students[3]. In addition, it can help students improve understanding, present interesting and reliable data, facilitate interpretation of data, and condense information.

Learning media is the greatest influence on the senses and can better ensure that the listener's understanding is not the same level of understanding and duration of what he or she understands compared to those who see, or see and hear it[6]. Furthermore, Ibrahim (1946) explained the importance of the media because the media generated a sense of joy and excitement for the students and renewed their passion of putting the knowledge on the minds of the students and living the lessons.

Television as a medium of audio visual teaching contains several advantages, among others: a). Direct and real, and can present the actual events, b). Expand classrooms, across regional or multiple countries, c). Can recreate past events, d). Can show many things and many diverse facets, e). Many use community resources, f). Interesting child, g). Can train teachers, both in pre-service and in in-services training, $h$ ). Television can present programs that can be understood by students with different ages and levels of education.

The lack of learning using television media are: a). Television is only capable of presenting one-way communication, b). Television at the time of broadcast will continue and there is no opportunity to understand the messages according to the individual student's abilities. c).
Teachers have no chance to revise the film before it is broadcast. d). the screen of a television set is not able to reach a large class making it difficult for all students to see in detail the broadcast images.

TV-E is one of the government television stations based under Pustekkom Kemdikbud which has a role in efforts to enliven the nation's children by presenting various quality educational broadcast services to support national education goals. The concept of education, television has an Educative Mission with guidelines as follows: a). Broadcast programs should be cultivated according to the needs of the intended audience, b). The content of broadcasts should be cultivated in accordance with the cultural values accepted by the people of Indonesia. c). Broadcast programs are endeavored to relate to existing activities in the community, d). Each eye of the event is endeavored to be developed in the form of a continuous package, e). Each program must be created with a certain direction and purpose[5].

TVE's vision is to be educational television broadcasting and educational. The mission is to broadcast programs that educate the community, become community leaders, disseminate information and policies of the Ministry of National Education, and encourage people to learn. The Ministry of National Education (MoNE) through Education and Information Technology Communication Center (Pustekkom) has launched the commencement of Education Television (TVE) in 2003. The hope of course educational television can add insight and intelligence.

Television watching activities can be regarded as a routine activity of every family in Indonesia. Every member of the family must have their own time to enjoy their favorite shows no children, but not all TV shows are good for children. Every family of course has their own filter about the allowances that are allowed for their children.

Children should indeed watch the impressions that support children's education. Such as children's educational programs from Pustekkom example animated children's character education films, with various subtitles include: 1. Children learn manners which is a short animated film that tells a child's process in learning manners in everyday life. 2. The importance of mutual cooperation that tells friendship and togetherness so that it can solve the problem well.

In addition to films that teach about character education there is also a short animated film that contains the introduction of letters, numbers, forms, recognize the limbs and many other short films of education that can be used as a medium that can be used as a child's education support. Media $\mathrm{TV}$ always refers to its role in the efforts of inheritance of noble values from one generation to the next, or from one group to another. George Gomstok argues that TV has become an inevitable and indispensable factor in making ourselves and what we will be like later (Pitriawanti, 2010)[7]. Because of the frequent time spent watching $\mathrm{TV}$, the stronger the influence TV will have on them is in the effort to inherit the noble values of a nation. That means the content that is on TV shows is directly able to shape and influence the child's character. 
Media TV which also has a function as a means of learning and disseminating the values contained in character education with a good TV show and educate. The influence of TV shows is very influential for consumers of TV media. One element of society that is vulnerable to the influence of TV shows is children and adolescents. They are an age group that has high imitation power. They tend to have great curiosity. One of them is against TV show object[8].

Based on this it can be concluded that the role of TV media has a very big influence in disseminating information and noble values. Thus the TV media is very useful in the business of character formation of children who are basically very close to the TV and tend to like to imitate the things he sees.

\section{CONCLUSION}

Television is a media that can be rely on to make education better. One such effort is the utilization of educational TV. With the TV education, it is expected that the educational process of children's character in Indonesia can run well. Utilization of TV Education as a medium of learning requires a clear design, teachers must first prepare materials suitable for students, and then after the learning process is completed should be held so that students not only just watch but really understand what the content of lessons in Inside.

Television as audio visual technology is very suitable for learning media. The existence of the advantages mentioned above make the learning process effective and efficient. Teachers will be easier to deliver lessons because these tools and students more quickly stimulate the subject matter as they can see firsthand.
One element of society that is vulnerable to the influence of TV shows is children and adolescents. They are an age group that has high imitation power. They tend to have great curiosity. One of them is against TV show object. Based on this it can be concluded that the role of TV media has a very big influence in disseminating information and noble values. Thus the TV media is very useful in establishment effort child character that is basically very close to TV and tends to like to imitate the things he sees.

\section{References}

[1] A. Gibbs, "Sympathy, synchrony, and mimetic communication," Affect theory Read., pp. 186-206, 2010.

[2] M. P. Trianto, "Mendesain Model Pembelajaran Inovatif-Progresif," Jakarta: Kencana, 2009.

[3] O. Hamalik, Proses belajar mengajar. Bumi Aksara, 2004.

[4] E. Ardianto, Komunikasi Massa. Bandung: Simbiosa Rekatama Media, 2007.

[5] Y. Miarso, Menyemai benih teknologi pendidikan. Kencana, diterbitkan atas kerja sama dengan Pustekkom-Diknas, 2004.

[6] A. Arsyad, Media Pembelajaran. Jakarta: Rajawali Press, 2009.

[7] R. Y. Muyaningsih, "The Influence of Advertising Exposure and Frequency of Parent-Children Communication towards Purchase Request Food and beverage Products from Children to Parent," Interak. Online, vol. 4, no. 2, pp. 1-12, 2016.

[8] R. Kriyantono, S. Sos, and M. Si, Teknik praktis riset komunikasi. Prenada Media, 2014. 